\title{
PENGARUH MODEL PEMBELAJARAN ANALISIS LAPANGAN DAN LABORATORIUM (MPALL) PADA MATERI INTERAKSI MAKHLUK HIDUP DENGAN LINGKUNGAN TERHADAP KETERAMPILAN BERPIKIR KRITIS IPA SISWA SMP
}

\author{
Wahyuning Putri Lestari ${ }^{1}$, Sutarto $^{2}$, Mochammad Iqbal ${ }^{3}$ \\ Fakultas Keguruan dan Ilmu Pendidikan, Universitas Jember \\ e-mail: putrilestariid1@gmail.com
}

\section{ABSTRAK}

Penelitian ini bertujuan untuk mengkaji pengaruh model pembelajaran analisis lapangan dan laboratorium (MPALL) pada materi interaksi makhluk hidup dengan lingkungan terhadap keterampilan berpikir kritis siswa SMP. Metode yang digunakan dalam penelitian ini adalah jenis penelitian quasi experimental dengan desain penelitian non-equivalent control group desain. Populasi pada penelitian ini yaitu peserta didik kelas VII SMPN 1 Purwoharjo. Metode yang digunakan untuk menentukan tempat penelitian adalah metode purposive sampling. Sampel ditentukan dengan menggunakan uji homogenitas berupa nilai pelajaran semester ganjil kelas VII. Sampel dalam penelitian ini yaitu kelas VII D sebagai kelas eksperimen dan kelas VII E sebagai kelas kontrol. Waktu penelitian dilaksanakan pada semester genap tahun ajaran 2020/2021. Instrument pengumpulan data berupa observasi, wawancara, dokumentasi dan tes. Data hasil penelitian yang diperoleh dianalisis menggunakan uji statistik berupa uji normalitas, uji homogenitas, uji independent sample $t$ test, dan uji $\mathrm{t}$ - pihak kanan. Hasil analisis data menggunakan uji independent sample $t$ test menunjukkan nilai Sig. (2-tailed) sebesar 0.000 yang artinya nilai lebih kecil dari pada (Sig. < 0.05) maka $\mathrm{H}_{\mathrm{o}}$ ditolak dan $\mathrm{H}_{\mathrm{i}}$ diterima. Sehingga, kesimpulan penelitian ini adalah pemanfaatan model pembelajaran analisis lapangan dan laboratorium (MPALL) pada materi interaksi makhluk hidup dengan lingkungan berpengaruh signifikan terhadap keterampilan berpikir kritis siswa

Kata Kunci: MPALL, Interaksi Makhluk Hidup dengan Lingkungan, Keterampilan Berpikir Keritis

\section{ABSTRACT}

This study aims to examine the effect of the field and laboratory analysis learning model (MPALL) on the interaction of living things with the environment on the critical thinking skills of junior high school students. The method used in this study is a quasi-experimental research design with a non-equivalent control group design. The population in this study were students of class VII SMPN 1 Purwoharjo. The method used to determine the place of research is purposive sampling method. The sample was determined using a homogeneity test in the form of grade VII odd semester lessons. The sample in this study is class VII D as the experimental class and class VII E as the control class. The time of the research was carried out in the even semester of the 2020/2021 academic year. Data collection instruments in the form of observations, interviews, documentation and tests. The research data obtained were 
analyzed using statistical tests in the form of normality test, homogeneity test, independent sample t test, and right side t test. The results of data analysis using the independent sample $t$ test showed the value of Sig. (2-tailed) of 0.000 which means that the value is smaller than (Sig. <0.05) then Ho is rejected and Hi is accepted. Thus, the conclusion of this study is that the use of the field and laboratory analysis learning model (MPALL) on the interaction of living things with the environment has a significant effect on students' critical thinking skills.

Keywords: MPALL, Interaction of Living Things with the Environment, Critical Thinking Skills

\section{PENDAHULUAN}

Pembelajaran IPA merupakan pembelajaran yang menekankan pada pemberian pengalaman langsung untuk mengembangkan kompetensi agar siswa dapat memahami secara luas tentang alam di sekitarnya secara ilmiah. Pembelajaran Ilmu Pengetahuan Alam juga merupakan suatu upaya atau proses yang mengajarkan siswa supaya mampu memahami hakikat IPA, yaitu berupa: produk, proses, serta mengembangkan keterampilan sikap ilmiah dan sadar akan nilai-nilai yang ada dalam masyarakat sebagai pengembangan keterampilan sikap serta perlakuan berupa pengaplikasian pada IPA dengan nilai positif (Pamungkas dan Linuwih, 2017). Pembelajaran IPA bukan hanya kumpulan pengetahuan yang berupa fakta, konsep atau prinsip saja, namun juga merupakan suatu proses penemuan (Mansur dan Salim, 2019). Oleh sebab itu untuk dapat memperoleh kegiatan pembelajaran yang baik, maka perlu adanya persiapan rancangan pembelajaran IPA yang tepat, dengan memberikan pengalaman secara langsung kepada siswa untuk dapat meningkatkan keterampilan berpikir kritis dan hasil belajar siswa.

Dalam proses pembelajaran keterlibatan siswa secara langsung sangatlah penting, namun beberapa pendapat menyebutkan bahwa rendahnya pemahaman siswa dalam menerima pembelajaran yang disampaikan oleh guru berasal dari kurangnya keterlibatan siswa secara langsung dalam proses pembelajaran. sehingga hal tersebut dapat menyebabkan keterampilan berpikir kritis siswa menjadi terhambat, selain itu siswa akan mengalami kesulitan dalam mengaitkan materi pelajaran dengan lingkungan sekitar yang terjadi di kehidupan sehari-hari (Fatmawati dan Sujatmika, 2018). Pada keterampilan berpikir kritis beberapa guru IPA menyatakan bahwa pada saat siswa diberikan suatu permasalahan, siswa masih sulit dalam menentukan solusi sendiri dan mengkomunikasikan masalah tersebut. Sehingga dapat dikatakan bahwa tingkat keterampilan berpikir kritis siswa masih cukup rendah, oleh karena itu perlunya dilakukan suatu pembelajaran yang dapat melatih keterampilan berpikir kritis siswa (Dewi Larasati dan Hidayati, 2018).

Berdasarkan uraian permasalahan tersebut, maka perlu adanya inovasi dalam proses pembelajaran guna untuk membangun keaktifan aktivitas siswa yaitu dengan menggunakan Model Pembelajaran Analisis Lapangan dan Laboratorium. Model Pembelajaran analisis Lapangan dan Laboratorium (MPALL) adalah suatu pengembangan dari dua kelompok model pembelajaran, yaitu model pemrosesan informasi dan model sosial (Bakhtiar et al., 2017). Model pembelajaran MPALL memiliki beberapa kelebihan yaitu siswa harus mencari atau menemukan informasi sendiri yang terdapat di lingkungannya, sehingga guru tidak langsung memberikan informasi kepada siswa. Dari hasil informasi yang ditemukan tersebut 
dapat diujikan langsung dengan referensi yang sudah baku, contohnya menggunakan jurnal atau buku dari hasil penelitian (Joyce et al., 2000).

Melalui Model Pembelajaran Analisis Lapangan dan Laboratorium (MPALL) siswa melakukan pembelajaran secara berkelompok dengan menganalisis kejadian nyata yang ada di lapangan atau di lingkungan sekitar yang berhubungan dengan materi, untuk mencari kebenaran mengenai hasil kegiatan lapangan, selanjutnya dilakukan dengan analisis laboratorium atau menggunakan teori yang sudah baku. Melalui hal tersebut siswa telah melakukan aktivitas belajar sesuai dengan hakikat belajar IPA yang dapat meningkatkan hasil belajar (Bakhtiar et al., 2017). Selain itu melalui pengamatan (observasi), secara langsung siswa akan dapat meningkatkan keterampilan berpikir kritis, karena di dalam MPALL memuat kegiatan belajar untuk menganalisis kejadian nyata yang ada dilingkungan yang berhubungan dengan konsep sains serta membahas keadaan yang terjadi secara nyata dengan melalui eksperimen atau laboratorium (Sutarto, 2012). Berdasarkan paparan di atas model pembelajaran analisis lapangan dan laboratorium (MPALL) diharapkan dapat meningkatkan keterampilan berpikir kritis siswa SMP pada materi interaksi makhluk hidup dengan lingkungan.

\section{METODE}

Metode penelitian yang digunakan dalam penelitian ini adalah dengan menggunakan jenis penelitian quasi eksperimen merupakan (penelitian semu) yaitu jenis penelitian yang pengambilan subjek penelitiannya dilakukan secara tidak acak (Hastharho, 2019). Pada penelitian ini terdapat dua kelompok yaitu kelas eksperimen dan kelas kontrol, keduanya menggunakan materi dan tujuan pembelajaran yang sama. Namun, pada kelas eksperimen adalah dengan menerapkan pembelajaran dengan menggunakan model pembelajaran analisis lapangan dan laboratorium (MPALL), sedangkan pada kelas kontrol menggunakan model pembelajaran konvensional atau model pembelajaran yang sering digunakan di sekolah.

Penelitian ini dilaksanakan di SMP Negeri 1 Purwoharjo pada semester genap tahun ajaran 2020/2021. Metode yang digunakan untuk menentukan tempat penelitian ini adalah metode purposive sampling yaitu dengan mempertimbangkan ketersediaan sekolah, ketersediaan waktu, sarana dan prasarana yang tersedia di sekolah. Populasi penelitian ini adalah siswa kelas VII SMP Negeri 1 Purwoharjo Sampel ditentukan dengan menggunakan uji homogenitas berupa nilai pelajaran semester ganjil kelas VII. Jumlah populasi dari seluruh kelas yaitu mulai dari kelas VII D sampai dengan VII H yang berjumlah 5 kelas adalah 150 siswa. Dimana didalam satu kelas terdapat 30 siswa. Sebelum dilakukan uji homogenitas maka terlebih dahulu dilakukan uji normalitas One-Sample Kolomogrov-Smirnov. Kemudian uji homogenitas menggunakan ONE Way Analisys of Varian (ANOVA). Sampel dalam penelitian ini yaitu kelas VII D sebagai kelas eksperimen berjumlah 25 siswa dan kelas VII E sebagai kelas kontrol berjumlah 25 siswa. Dari setiap kelas hanya diambil 25 siswa karena 5 siswa lainnya kurang optimal dalam mengikuti proses pembelajaran. Teknik dan instrumen utama pada penelitian ini pengambilan data dilakukan dengan menggunakan tes sebelum (pre-test) dan sesudah (post-test) yang sesuai dengan indikator yang ada pada materi interaksi makhluk hidup dengan lingkungan yaitu berupa tes keterampilan berpikir kritis. Teknik dan 
instrumen pendukung yang digunakan data penelitian ini adalah observasi, wawancara, dan dokumentasi.

Teknik analisis data yang digunakan adalah uji normalitas yang dilakukan terlebih dahulu. Apabila data berdistribusi normal maka dapat dilanjutkan dengan menggunanakn uji homogenitas kemudian dilanjutkan dengan menggunakan uji independent sampel t test sedangkan jika data tidak berdistribusi normal maka dilakukan uji Mann Whitney U Test. Jika telah diketahui perbedaan rata-rata kedua kelas, maka dapat dilakukan uji t - pihak kanan. Desain penelitian eksperimen yang digunakan dalam penelitian ini yaitu NonEquivalent control group Design. Menurut Khoirunisyah (2016) Non-Equivalent control group Design ialah desain penelitian dimana kedua kelas baik kelas kontrol maupun kelas eksperimen tidak dipilih secara random.

\begin{tabular}{|lccc|}
\hline Kelompok & Pretest & Perlakuan & Postest \\
\cline { 2 - 4 } Kelas Eksperimen & $\mathrm{O}_{1}$ & $\mathrm{X}$ & $\mathrm{O}_{2}$ \\
\cline { 2 - 4 } Kelas Kontrol & $\mathrm{O}_{3}$ & & $\mathrm{O}_{4}$ \\
\hline
\end{tabular}

Gambar 1 Desain non-equivalent control group design

(Irawan, 2020)

Keterangan:

$\mathrm{X}=$ Perlakuan dengan menggunakan Model Pembelajaran analisis lapangan dan laboratorium

(MPALL)

$\mathrm{O}_{1}=$ tes kemampuan awal kelas eksperimen

$\mathrm{O}_{2}=$ tes kemampuan akhir kelas eksperimen

$\mathrm{O}_{3}=$ tes kemampuan awal kelas kontrol

$\mathrm{O}_{4}=$ tes kemampuan akhir kelas kontrol

Hipotesis statistik yang diajukan pada keterampilan berpikir kritis siswa dalam penelitian yaitu:

1) Jika nilai Sig. (2-tailed) $<0.05$, maka terdapat perbedaan yang signifikan antara kedua kelas $\left(\mathrm{H}_{\mathrm{o}}\right.$ ditolak)

2) Jika nilai Sig. (2-tailed) $>0.05$, maka tidak berbeda secara signifikan antara kedua kelas $\left(\mathrm{H}_{\mathrm{o}}\right.$ diterima) (Rosdiana, 2017).

Uji hipotesis statistik uji $\mathrm{t}$ - pihak kanan adalah uji $\mathrm{t}$ - pihak kanan digunakan apabila $\mathrm{H}_{\mathrm{o}}$ lebih kecil atau sama dengan $(\leq)$ dan $\mathrm{H}_{\mathrm{i}}$ lebih besar $(>)$. Sebelum dilakukan uji $\mathrm{t}-$ pihak kanan, maka perlu terlebih dahulu diketahui hipotesis statistik sebagai berikut:

$\mathrm{H}_{\mathrm{o}}: \mathrm{R}_{1} \leq \mathrm{R}_{2}$ (nilai rata-rata kelas eksperimen tidak lebih baik dibandingkan dengan kelas kontrol)

$\mathrm{H}_{1}: \mathrm{R}_{1}>\mathrm{R}_{2}$ (nilai rata-rata kelas eksperimen lebih baik dibandingkan dengan kelas kontrol)

Keterangan: $\mathrm{R}_{1}=$ Kelas eksperimen

$\mathrm{R}_{2}=$ Kelas kontrol

Selanjutnya perlu diketahui ketentuan iji statistik sebagai dasar pengambilan keputusan pada uji $\mathrm{t}$ - pihak kanan adalah sebagai berikut: 
a. Jika $t_{\text {hitung }}<t_{\text {tabel }}$ maka $H_{o}$ (hipotesis nihil) diterima dam $\mathrm{H}_{\mathrm{i}}$ (hipotesis alternatif) ditolak

b. Jika $t_{\text {hitung }}>t_{\text {tabel }}$ maka $H_{o}$ (hipotesis nihil) ditolak dam $H_{i}$ (hipotesis alternatif) diterima (Syafril, 2019).

\section{HASIL DAN PEMBAHASAN}

Data yang diperoleh melalui Teknik dan instrument pendukung dengan tujuan untuk memperoleh data utama yang sesuai pada penelitian ini adalah observasi, wawancara, dan dokumentasi. Observasi ini dilakukan dengan tujuan untuk mengetahui persiapan siswa, pembelajaran yang dilakukan oleh guru serta aktivitas peserta didik dalam proses pembelajaran berlangsung. Dalam penelitian ini terdapat beberapa hal yang akan diamati yaitu tes hasil belajar, keterampilan berpikir kritis siswa dan proses pembelajaran sebelum dan sesudah memanfaatkan model pembelajaran analisis lapangan dan laboratorium (MPALL) pada materi interaksi makhluk hidup dengan lingkungan. Dari data observasi persiapan siswa kelas eksperimen maupun kelas kontrol memiliki persiapan yang sama-sama baik saat aktivitas belajar dimulai. Kemudian, Wawancara dilakukan dengan tujuan untuk mengetahui kendala yang dialami pada saat proses pembelajaran dikelas yang dilakukan kepada guru IPA kelas VII SMPN 1 Purwoharjo. Selanjutnya yaitu dokumentasi yang dilakukan dalam penelitian ini adalah proses pengumpulan data yang berupa: nama siswa, jadwal mata pelajaran IPA kelas VII SMP tahun ajaran 2020/2021, gambar atau video dari kegiatan (proses) pembelajaran, nilai Pretest, nilai Postest, lembar penilaian, dan dokumen lain yang dapat mendukung penelitian.

Data hasil keterampilan berpikir kritis siswa diperoleh dari nilai pre-test dan nilai post-test pada materi interaksi makhluk hidup dengan lingkungan. Soal pre-test dan post-test yang diberikan kepada siswa berjumlah 5 soal essay yang telah disesuaikan terlebih dahulu menggunakan indikator keterampilan berpikir kritis menurut Fascione (2015). Skor rata-rata nilai pre-test dan post-test keterampilan berpikir kritis siswa pada kelas eksperimen dan kelas kontrol dapat dilihat pada Tabel 1.

Tabel 1 Rata-rata nilai tes keterampilan berpikir kritis

\begin{tabular}{|l|l|c|c|c|}
\hline \multicolumn{1}{|c|}{ Kelas } & \multicolumn{1}{|l|}{$\begin{array}{l}\text { Jumlah } \\
\text { Siswa }\end{array}$} & Pre-test & Post-test & \multicolumn{1}{l|}{ Selisih } \\
\hline Eksperimen & $\mathbf{2 5}$ & 67.32 & 80.08 & 12.76 \\
\hline Kontrol & $\mathbf{2 5}$ & 61.00 & 69.16 & 8.16 \\
\hline
\end{tabular}

Berdasarkan Tabel 1 menunjukkan perolehan rata-rata nilai tes keterampilan berpikir kritis siswa antara kelas kontrol dan kelas eksperimen. Dari data tersebut menunjukkan bahwa kelas eksperimen memiliki rata-rata nilai lebih tinggi dibandingkan dengan kelas kontrol.

Setelah diketahui nilai perbandingan dari kelas ekperimen dan kelas kontrol dengan menggunakan pre-test dan post-test, maka selanjutnya dilakukan uji normalitas. Berdasarkan hasil dari uji normalitas menggunakan Kolmogrov-Smirnov didapatkan hasil pada kelas eksperimen nilai pre-test besar signifikasinya adalah 0.065 dan nilai post-test sebesar 0.56 . Kemudian, pada kelas kontrol nilai pre-test besar signifikasinya adalah 0.068 dan nilai post- 
test sebesar 0.059. Sehingga secara sistematis data nilai keterampilan berpikir kritis siswa pada kelas eksperimen dan kelas kontrol adalah berdistribusi normal. Output uji normalitas terhadap keterampilan berpikir kritis siswa dapat dilihat pada Tabel 2.

Tabel 2. Uji normalitas keterampilan berpikir kritis siswa

\begin{tabular}{|c|l|c|r|r|r|r|c|}
\hline \multicolumn{9}{|c|}{ Tests of Normality } \\
\hline \multirow{3}{*}{} & \multirow{3}{*}{ Kelas } & \multicolumn{2}{|c|}{ Kolmogorov-Smirnov } & \multicolumn{3}{|c|}{ Shapiro-Wilk } \\
\cline { 3 - 8 } & & Statistic & df & Sig. & Statistic & Df & Sig. \\
& & & & & & & \\
\hline Pretest & Kelas Eksperimen & .169 & 25 & .065 & .939 & 25 & .141 \\
\cline { 2 - 8 } & Kelas Kontrol & .168 & 25 & .068 & .932 & 25 & .099 \\
\hline Posttest & Kelas Eksperimen & .171 & 25 & .056 & .929 & 25 & .084 \\
\cline { 2 - 8 } & Kelas Kontrol & .170 & 25 & .059 & .940 & 25 & .145 \\
\hline
\end{tabular}

Selenjutnya dilakukan uji homogenitas yaitu dengan menggunakan uji Levene pada kedua kelas yaitu kelas eksperimen dan kelas kontrol berdasarkan nilai pre-test dan post-test keterampilan berpikir kritis siswa. Hasil output uji homogenitas dapat dilihat pada Tabel 3.

Tabel 3. Hasil uji homogenitas keterampilan berpikir kritis siswa

\begin{tabular}{|c|c|c|c|c|c|}
\hline \multicolumn{6}{|c|}{ Test of Homogeneity of Variance } \\
\hline & & $\begin{array}{l}\text { Levene } \\
\text { Statistic }\end{array}$ & df1 & df2 & Sig. \\
\hline \multirow[t]{4}{*}{ Pre-test } & Based on Mean & .182 & 1 & 48 & .671 \\
\hline & Based on Median & .123 & 1 & 48 & .727 \\
\hline & $\begin{array}{l}\text { Based on Median } \\
\text { and with adjusted } \\
\text { df }\end{array}$ & .123 & 1 & 47.107 & .727 \\
\hline & $\begin{array}{l}\text { Based on trimmed } \\
\text { mean }\end{array}$ & .178 & 1 & 48 & .675 \\
\hline \multirow[t]{4}{*}{ Post-test } & Based on Mean & .220 & 1 & 48 & .641 \\
\hline & Based on Median & .121 & 1 & 48 & .730 \\
\hline & $\begin{array}{l}\text { Based on Median } \\
\text { and with adjusted } \\
\text { df }\end{array}$ & .121 & 1 & 45.943 & .730 \\
\hline & $\begin{array}{l}\text { Based on trimmed } \\
\text { mean }\end{array}$ & .225 & 1 & 48 & .638 \\
\hline
\end{tabular}

Berdasarkan data hasil nilai pre-test dan post-test pada keterampilan berpikir kritis siswa diketahui bahwa nilai signifikasi pre-test dan post-test pada kelas eksperimen dan kelas kontrol adalah berdistribusi normal yaitu nilai pre-test besar signifikasinya adalah 0.675 $(\mathrm{p}=0.675>0.01)$ dan nilai post-test adalah $0.638(0.638>0.01)$ yang artinya data nilai hasil keterampilan berpikir kritis pre-test dan post-test pada kelas eksperimen dan kelas kontrol bersifat homogen atau memiliki varian yang sama. Maka selanjutnya akan dilakukan uji 
independent sample t-test sebagai uji parametrik untuk mengetahui data berdistribusi normal atau tidak. Apabila data diketahui tidak berdistribusi normal maka akan dilanjutkan dengan menggunakan uji Mann-Whitney U Test sebagai uji non-parametrik. Hasil uji independent sample t-test dapat diamati pada Tabel 4.

Tabel 4. Uji independent sample t-test keterampilan berpikir kritis siswa

\begin{tabular}{|c|c|c|c|c|c|c|c|c|}
\hline \multicolumn{9}{|c|}{ Independent Samples Test } \\
\hline & & \multicolumn{2}{|c|}{$\begin{array}{l}\text { Levene's } \\
\text { Test for } \\
\text { Equality of } \\
\text { Variances } \\
\end{array}$} & \multicolumn{5}{|c|}{ t-test for Equality of Means } \\
\hline & & $\mathrm{F}$ & Sig. & $\mathrm{t}$ & df & $\begin{array}{l}\text { Sig. (2- } \\
\text { tailed) }\end{array}$ & $\begin{array}{c}\text { Mean } \\
\text { Differen } \\
\text { ce }\end{array}$ & $\begin{array}{l}\text { Std. Error } \\
\text { Difference }\end{array}$ \\
\hline \multirow[t]{2}{*}{ Pretest } & $\begin{array}{l}\text { Equal } \\
\text { variances } \\
\text { assumed }\end{array}$ & .182 & .671 & 2.377 & 48 & .021 & 6.320 & 2.659 \\
\hline & $\begin{array}{l}\text { Equal } \\
\text { variances not } \\
\text { assumed }\end{array}$ & & & 2.377 & 47.439 & .022 & 6.320 & 2.659 \\
\hline \multirow[t]{2}{*}{ Posttest } & $\begin{array}{l}\text { Equal } \\
\text { variances } \\
\text { assumed }\end{array}$ & .220 & .641 & 4.106 & 48 & .000 & 10.840 & 2.640 \\
\hline & $\begin{array}{l}\text { Equal } \\
\text { variances not } \\
\text { assumed }\end{array}$ & & & 4.106 & 47.205 & .000 & 10.840 & 2.640 \\
\hline
\end{tabular}

Berdasarkan hasil uji Independent sample $t$ test keterampilan berpikir kritis siswa pada Tabel 4.3 dapat diketahui bahwa nilai pre-test pada kelas eksperimen Sig (2-tailed) sebesar 0.021 dan pada kelas kontrol sebesar 0.022 yang berarti nilainya lebih kecil dari (Sig. $<0.05$ ), dan untuk nilai post-test pada kelas eksperimen dan kelas kontrol menunjukkan bahwa Sig (2-tailed) sebesar 0.000 yang berarti nilainya lebih kecil dari pada (Sig. < 0.05). Sesuai dengan kriteria pengujian yang telah ditentukan yaitu

1) Jika nilai Sig. (2-tailed) <0.05, maka terdapat perbedaan yang signifikan antara kedua $\left(\mathrm{H}_{\mathrm{o}}\right.$ ditolak $)$

2) Jika nilai Sig. (2-tailed) $>0.05$, maka tidak terdapat perbedaan yang signifikan antara kedua $\left(\mathrm{H}_{\mathrm{o}}\right.$ diterima)

Sehingga sesuai dengan pedoman dasar pengambilan keputusan dimana $\mathrm{H}_{0}$ ditolak dan $\mathrm{H}_{\mathrm{i}}$ diterima, maka dapat disimpulkan melalui nilai pre-test dan post-test menunjukkan bahwa keterampilan berpikir kritis siswa pada kelas eksperimen dan kelas kontrol terdapat perbedaan yang signifikan. Selanjutnya dilakukan uji $\mathrm{t}$ - pihak kanan. Hipotesis statistis dan kriteria uji statistik pada keterampilan berpikir kritis sama halnya dengan yang telah dijelakan sebelumnya. Hasil uji $\mathrm{t}$ - pihak kanan pada keterampilan berpikir kritis siswa dapat dilihat pada Tabel 5. 
Tabel 5. Hasil uji t-pihak kanan keterampilan berpikir kritis

\begin{tabular}{|lcccc|}
\hline Kelas & $\mathrm{N}$ & Mean & $\mathrm{t}_{\text {hitung }}$ & $\mathrm{t}_{\text {tabel }}$ \\
\hline Kelas Eksperimen & 25 & & & 1.677 \\
Pretest & & 67.32 & 2.377 & \\
Postest & & 80.08 & 4.106 & \\
Kelas Kontrol & 25 & & & 1.677 \\
Pretest & & 61.00 & 2.377 & \\
Postest & & 69.16 & 4.106 & \\
\hline
\end{tabular}

Tabel 5 menunjukkan bahwa uji t - pihak kanan pada hasil belajar kognitif siswa adalah nilai $t_{\text {tabel }}$ pada tabel distribusi $t$ dengan taraf signifikasi 0.05 sebesar 1.677 , sedangkan hasil perhitungan $t_{\text {hitung }}$ sebesar 2.377 pada nilai pretest dan 4.106 pada nilai post-test. Hasil perhitungan tersebut menunjukkan bahwa $t_{\text {hitung }}>t_{\text {tabel }}$, maka dapat disimpulkan bahwa $\mathrm{H}_{\mathrm{o}}$ ditolak dan $\mathrm{H}_{\mathrm{i}}$ diterima yang artinya nilai rata-rata kelas eksperimen lebih baik dibandingkan dengan kelas kontrol.

Sehingga dapat dikatakan bahwa model pembelajaran analisis lapangan dan laboratorium (MPALL) pada materi interaksi makhluk hidup dengan lingkungan berpengaruh terhadap keterampilan berpikir kritis siswa. Hasil penelitian yang diperoleh hampir serupa dengan pernyataan Sutarto (2012) Model pembelajaran analisis Lapangan dan Laboratorium (MPALL) adalah model pembelajaran yang memuat kegiatan belajar untuk menganalisis kejadian nyata yang ada dilingkungan yang berhubungan dengan konsep sains serta membahas keadaan yang terjadi secara nyata dengan melalui eksperimen atau laboratorium sehingga secara langsung hal tersebut dapat meningkatkan keterampilan berpikir kritis siswa. Menurut hasil penelitian dari Oktaviarini (2017) menunjukkan bahwa keterampilan berpikir kritis siswa menunjukkan peningkatan pada siklus I ke siklus II. Pengembangan siklus keterampilan berpikir kritis siswa di peroleh melalui keterlibatan pembelajaran di luar kelas dan pengalaman nyata yang diperoleh siswa dalam pembelajaran. Pembelajaran dengan melibatkan lingkungan juga dapat membantu siswa dalam meningkatkan pengetahuan yang sedang dipelajari. Menurut Sofa, dkk (2020) pembelajaran yang dilakukan di lapangan dapat berdampak positif terhadap keterampilan berpikir kritis siswa, selain dapat meningkatkan semangat belajar siswa, hal tersebut juga dapat menambah wawasan siswa karena dapat secara langsung melihat objek pembelajaran secara langsung. Sejalan dengan pendapat Samsudin (2016) yaitu dengan melakukan pembelajaran yang lebih mendekatkan siswa dengan sumber belajar yang sesungguhnya dapat membantu siswa dalam menghubungkan materi dengan konsep pembelajaran secara nyata yang ada dilingkungan sekitar. Melalui hal tersebut siswa juga dapat menerima pembelajaran dengan tidak hanya mengira-ngira atau hanya membayangkan objek pembelajaran yang akan dipelajari, sehingga dengan cara ini siswa dapat meningkatkan keterampilan berpikir kritis terhadap konsep-konsep IPA yang ada di kehidupan sehari-hari.

\section{PENUTUP}

Berdasarkan pada hasil penelitian ini dapat disimpulkan bahwa pembelajaran IPA dengan menggunakan model pembelajaran analisis lapangan dan laboratorium (MPALL) 
memiliki rata-rata yang lebih tinggi dibandingkan dengan pembelajaran konvensional dalam meningkatkan keterampilan bepikir kritis siswa.

Penggunaan model pembelajaran analisis lapangan dan laboratorium (MPALL) memiliki pengaruh positif dalam pembelajaran dengan memanfaatkan lingkungan yang ada di sekitar dapat membuat siswa lebih tertarik dalam melaksanakan pembelajaran. Siswa juga akan lebih mudah dalam mengaplikasikan konsep yang didapat dengan melakukan analisis lapangan secara langsung dalam pembelajarannya.

\section{UCAPAN TERIMA KASIH}

Ucapan terimakasih disampaikan terutama kepada semua pihak yang tidak dapat disebutkan satu-persatu yang telah membantu dan memberi dukungan dalam penyelesaian penelitian ini.

\section{DAFTAR PUSTAKA}

Bakhtiar, D., Supriadi, B., dan Gani, A. A. 2017. Pembelajaran Teori Kinetik Gas Berbasis Kearifan Lokal Melalui Model Pembelajaran Aktivitas Lapangan dan Laboratorium (MPALL). FKIP e-Proceeding, 2(1), 5-5.

Dewi Larasati, A. R. D. I. A., dan Nurul Hidayati, S. I. T. I. 2018. Keterampilan Berfikir Kritis Siswa Berbasis Model Guided Discovery pada Materi Interaksi Antar Makhluk Hidup. Pensa E-Jurnal: Pendidikan Sains, 6(02).

Fatmawati, E. T. dan S. Sujatmika. 2018. Efektivitas Pembelajaran Problem Based Learning Terhadap Hasil Belajar IPA Ditinjau Dari Kemampuan Berpikir Kritis. Wacana Akademika. 2(2): 163-171.

Hardisman, 2020. Tanya Jawab Analisis Data: Prinsip Dasar dan Langkah-Langkah Praktis Aplikasi pada Penelitian Kesehatan dengan SPSS. Sumatera Barat: Guepedia

Hastjarjo,T. 2019. Rancangan eksperimen-kuasi. Buletin Psikologi. 27 (2) : 187 - 203

Irawan, D. 2020. Pengembanagan Buku Teks Pembelajaran Membaca Berbasis Pendekatan Proses untuk SD. Purwokerto: Penapersada

Jamaluddin, J., Jufri, A. W., Muhlis, M., \& Bachtiar, I. 2020. Pengembangan Instrumen Keterampilan Berpikir Kritis Pada Pembelajaran IPA di SMP. Jurnal Pijar Mipa, 15(1), 13-19.

Mansur, M., dan Salim, A. 2019. Penerapan Model Pembelajaran Problem Based Learning (Pbl) Untuk Meningkatkan Hasil Belajar Ipa-Fisika Siswa Kelas VII C SMP Negeri 1 Ternate.Saintifik@,3(1).

Maulana. 2017. Konsep Dasar Matematika dan Pengembangan Kemampuan Berpikir KritisKreatif. Sumedang: UPI Sumedang Press

Melisa, 2020. Siapa Bilang Mengajar Matematika Sulit. Sumatera Barat: Guepedia

Pamungkas, A., Subali, B., dan Linuwih, S. 2017. Implementasi model pembelajaran IPA berbasis kearifan lokal untuk meningkatkan kreativitas dan hasil belajar siswa. Jurnal Inovasi Pendidikan IPA, 3(2), 118-127.

Samsudin, M. D. I. 2016. Pengaruh Pembelajaran Model Observasi Lapangan (Outdoor Study) dan Pembelajaran Inquiry terhadap Hasil Belajar Mata Pelajaran Sosiologi Siswa IPS SMA Negeri 3 Probolinggo. Jurnal Penelitian dan Pendidikan IPS, 10(2), 261-276.

Sofa, S. Z., Juniarso, T., dan Pramulia, P. 2020. Implementasi Pembelajaran Di Luar Kelas Berbasis Keterampilan Berpikir Kritis Siswa Pada Kelas V Tema 4 Subtema 1 Pembelajaran 4 SDN Ketabang Surabaya. Buana Pendidikan: Jurnal Fakultas Keguruan dan Ilmu Pendidikan, 16(30s), 13-26. 
Sutarto, 2012. Pembelajaran Secara Nominal dan Fungsional Sebagai Reoritasi Pendidikan Sains. Prosiding Seminar Nasional Sains

Oktaviarini, N. 2017. Penerapan Model Character Project Citizen (Cpc) Berbasis Outdoor Study Untuk Meningkatkan Kemampuan Berpikir Kritis Ips (Studi Pada Siswa Kelas Iv Sdn Talun 05 Kecamatan Talun Kabupaten Blitar). Jurnal Pendidikan dan Pembelajaran Anak Sekolah Dasar, 2(02). 